\title{
Articles
}

\section{Ex Parte McCardle and the Attorney General's Duty to Defend Acts of Congress}

\author{
By JOHN E. BeERbower*
}

\section{Introduction}

Over the YEARS, Attorneys General of the United States have professed the view that their office "has a duty to defend and enforce both the Acts of Congress and the Constitution." ${ }^{1}$ Consequently, as a general rule, Attorneys General have consistently affirmed that it is not the place of their office to declare statutes unconstitutional. When faced with a legislative act that they believe violates the Constitution, the Attorney General "can best discharge the responsibilities of his office by defending and enforcing the Act of Congress." 2 The reason

* Law Clerk, United States District Court for the Eastern District of Virginia. J.D. 2012, University of Virginia School of Law; M.Litt. 2008, University of St Andrews; B.A. 2006, Amherst College. I am immensely grateful to Professor Charles McCurdy for his guidance during the creation of this Article. Thank you also to my father and my wife, Megan, for their support and thoughtful comments. I am additionally grateful to the editors of the University of San Francisco Law Review for their skillful assistance. All errors are my own.

1. 4A Op. O.L.C. 55, 55 (1980).

2. Id.; see also 40 Op. Att'y Gen. 158, 160 (1942) ("[T] here are grave objections to the rendition of opinions by the Attorney General upon requests from the heads of the Federal departments and independent establishments concerning the constitutionality of laws they have been appointed to administer."); 39 Op. Att'y Gen. 11, 14 (1937) (“[T]here rarely can be proper occasion for the rendition of an opinion by the Attorney General upon [an act's] constitutionality after it has become law."); 38 Op. Att'y Gen. 252, 253 (1935) (" $[\mathrm{I}] \mathrm{t}$ does not lie within the province of a ministerial officer to question the validity of a statute which, in so far as he is concerned, merely imposes upon him a proper duty and has no bearing upon his constitutional rights."); 31 Op. Att'y Gen. 475, 476 (1919) ("Ordinarily, I would be content to say that it is not within the province of the Attorney General to declare an Act of Congress unconstitutional ...."). But see 9 Op. Att'y Gen. 462, 469 (1860) ("Every law is to be carried out so far forth as is consistent with the Constitu- 
for this position is inherent in our system of checks and balances and the constitutional separation of powers. ${ }^{3}$ Whereas "[i] t is emphatically the province and duty of the judicial department to say what the law is," 4 the executive branch must "take Care that the Laws be faithfully executed." Allowing the Attorney General-a member of the executive branch-to pass on the constitutionality of an act of Congress "could jeopardize the equilibrium established within our constitutional system."6 The delicate balance created by the separation of powers between the three branches of government is imperiled when one branch assumes the province of another.

Despite this seemingly explicit and unambiguous division of powers, there have been numerous occasions in which the Attorney General, acting either on his own behalf or upon the instruction of the President, has refused to defend an act of Congress. Most recently, Attorney General Eric Holder announced to Congress that President Barack Obama had concluded that Section 3 of the Defense of Marriage $\mathrm{Act}^{7}$ was unconstitutional and that the Justice Department would not defend that section's constitutionality in any pending or subsequently filed case. ${ }^{8}$ Predictably, this announcement was met with partisan uproar. ${ }^{9}$ Similarly, when the Reagan Administration refused to defend aspects of the Corporation for Public Broadcasting Act against a constitutional challenge in League of Women Voters v. FCC, ${ }^{10}$ the decision was lambasted as mere politics and an executive usurpation of

tion, and no further. The sound part of it must be executed, and the vicious portion of it suffered to drop.").

3. See U.S. Const. art. I, $§ 1$ ("All legislative Powers ... [are] vested in a Congress of the United States ...."); Id. art. II, $\$ 1$ ("The executive Power [is] vested in a President of the United States of America."); id. art. III, $§ 1$ ("The judicial Power of the United States, [is] vested in one supreme Court ....").

4. Marbury v. Madison, 5 U.S. (1 Cranch) 137, 177 (1803).

5. U.S. Const. art. II, § 3 .

6. 4A Op. O.L.C. 55, 56 (1980).

7. 1 U.S.C. $\$ 7$ (2006).

8. Letter from U.S. Att'y Gen. Eric Holder to U.S. House Speaker John Boehner (Feb. 23, 2011), available at http://www.justice.gov/opa/pr/2011/February/11-ag-223. html.

9. See, e.g., Defending Marriage: Hearing Before the Subcomm. on the Constitution of the H. Comm. on the Judiciary, 112th Cong. 1 (2011) (statement of Rep. Trent Franks) ("When the President unilaterally declares a duly enacted law unconstitutional, he cuts Congress and the American people out of the lawmaking process, and such heavy-handed Presidential actions undermine the separation of powers and the principle that America is a constitutional Republic predicated on the rule of law.").

10. 489 F. Supp. 517 (C.D. Cal. 1980). 
legislative power. ${ }^{11}$ The main difference in these two situations is the party affiliation of the vocal critics.

Many scholarly attempts to discuss the Attorney General's role in deciding whether to enforce or defend a particular statute have been prepared by former Attorneys or Solicitors General themselves. ${ }^{12}$ Much of that discussion has focused on the unique role of the Solicitor General in the modern era. ${ }^{13}$ Scholarly focus on the Solicitor General's office is understandable, because most contemporary commentary mistakenly claims that executive refusal to defend statutes is a recent development. ${ }^{14}$ To the contrary, Attorneys General have been declining to defend the government going at least as far back as Marbury $v$. Madison. ${ }^{15}$

11. See, e.g., Note, Executive Discretion and the Constitutional Defense of Statutes, 92 YAlE L.J. 970, 976-81 (1983).

12. This includes, more generally, scholarly attempts to discuss the interplay between the Attorney General's (and later the Solicitor General's) role as both chief litigator for the United States and political official. See, e.g., Griffin Bell, The Attorney General: The Federal Government's Chief Lawyer and Chief Litigator, or One Among Many?, 46 FordHAM L. Rev. 1049 (1978) (Attorney General to President Carter); Drew S. Days III, In Search of the Solicitor General's Clients: A Drama with Many Characters, 83 Ky. L.J. 485 (1994) (Solicitor General to President Clinton); Walter Dellinger, Legal Opinion from the Office of Legal Counsel to the Hon. Abner J. Mikva, 48 Ark. L. Rev. 313 (1995) (Solicitor General to President Clinton); Erwin Griswold, The Office of the Solicitor General-Representing the Interests of the United States before the Supreme Court, 35 Mo. L. Rev. 527 (1969) (Solicitor General to Presidents Lyndon Johnson and Richard Nixon); Simon E. Sobeloff, Attorney for the Government: The Work of the Solicitor General's Office, 41 A.B.A. J. 229 (1955) (Solicitor General to President Eisenhower, discussing Solicitor Generals' refusal to appeal cases to the Supreme Court); Seth Waxman, Defending Congress, 79 N.C. L. Rev. 1073 (2001) (Solicitor General to President Clinton). Of course, the seminal work on the history of the Attorney General remains HoMER Cummings \& Carl McFarland, Federal Justice (1937).

13. See generally supra note 12. Created along with the Justice Department in 1870, the Solicitor General bears the responsibility, under the supervision of the Attorney General, to "attend to the interests of the United States in a suit pending in a court of the United States." 28 U.S.C. $§ 517$ (2006). The Solicitor General is also responsible for "[c] onducting . . all Supreme Court cases," 28 C.F.R. $\$ 0.20$ (a) (2010), and "[d] etermining whether, and to what extent, appeals will be taken by the Government to all appellate courts." Id. $\S 0.20$ (b). The Solicitor General is the only person in the executive branch statutorily required to be "learned in the law." 28 U.S.C. $\$ 505$ (2006). When the office was originally created, the Attorney General was required to be "a meet person, learned in the law." An Act to Establish the Judicial Courts of the United States, ch. 20, § 35, 1 Stat. 92, 92 (1789). The requirement was extended to the Solicitor General with the creation of the Justice Department, and the office of the Solicitor General, in 1870. An Act to Establish the Department of Justice, ch. 142, § 1, 16 Stat. 162, 162 (1870).

14. See, e.g., Arthur Miller \& Jeffrey Bowman, Presidential Attacks on the Constitutionality of Federal Statutes: A New Separation of Powers Problem, 40 Oніо ST. L.J. 51, 51 (1979) (describing the practice as "newly emergent").

15. 5 U.S. (1 Cranch) 137 (1803). In Marbury, Attorney General Levi Lincoln, while nominally counsel for Secretary of State James Madison, refused to appear and only submitted written responses to questions of the Court when subpoenaed. Marbury, 5 U.S. (1 
More significantly, in Ex Parte McCardle, ${ }^{16}$ Attorney General Henry Stanbery refused to defend the Reconstruction Acts of 1867 on the grounds that he found them unconstitutional. ${ }^{17}$ Stanbery instructed the War Department to engage other counsel and the Department employed two sitting senators, Lyman Trumbull of Illinois and Matthew Carpenter of Wisconsin. This marked the first time in United States history that an act of Congress was actively represented by Congress itself, rather than by a member of the executive branch.

The case itself became more famous for its outcome than for the counsel that represented the parties. ${ }^{18}$ Nevertheless, McCardle presents an oft-overlooked first instance of public debate over an Attorney General's refusal to appear in defense of a statute on the grounds that he believed the it to be unconstitutional. Contemporary discussion of Stanbery's decision, both in the newspapers and in Congress, closely resembled the discussion that is had in similar situations today. This evidences both the timelessness of the issues raised by these executive decisions, as well as the lack of progress made toward resolving them over the past 140 years.

The goal of this Article is to demonstrate that the Attorney General's practice of refusing to defend statutes he views as unconstitutional is long-standing. Neither this phenomenon nor the debate surrounding it is "newly emergent," as is often asserted. ${ }^{19}$ Rather, although commentators and congressmen frequently profess hypocritical surprise that the other side would dare do such a thing, the exercise of executive discretion in appearing on behalf of the government has been present since the earliest days of the republic. This Article will paint a historical picture of the executive branch's selective refusal to defend the United States in federal courts, and will offer some conclusions on the propriety of that practice. Part I will provide a historical

Cranch) at 143 ("Mr. Lincoln, attorney general, having been summoned, and now called, objected to answering. He requested that the questions might be put in writing, and that he might afterwards have time to determine whether he would answer.").

16. 74 U.S. (7 Wall.) 506 (1869).

17. 6 Charles Fairman, History of the Supreme Court of the United States: ReCONSTRUCTION AND Reunion 1868-88, at 436 (1971).

18. Before the Court announced a result, Congress legislatively stripped the Court of its jurisdiction over the case. See An Act to Amend an Act entitled "An Act to Amend the Judiciary Act, passed twenty-fourth of September, seventeen hundred and eighty-nine," ch. 34, § 2, 15 Stat. 44, 44 (1868) (repealing the Habeas Corpus Act of 1867 "as authorizes an appeal from the judgment of the circuit court to the Supreme Court of the United States, or the exercise of any such jurisdiction by said Supreme Court on appeals which have been ... taken"). For further discussion on the counsel that represented the parties in McCardle, see infra Part II.B.3.

19. See, e.g., Miller \& Bowman, supra note 14, at 51. 
sketch of the Attorney General's role in defending the United States in litigation. It will also lay out the conventional doctrine for when it is traditionally appropriate for the Attorney General to decline to defend. Part II will explore several of the earliest examples of refusals to defend, with a discussion of Marbury $v$. Madison and United States $v$. Hudson $\mathcal{E}^{2}$ Goodwin, ${ }^{20}$ with particular focus on what appears to be the first real example of an Attorney General refusing to defend an otherwise defensible statute, Ex Parte McCardle. Part III will discuss some of the questions raised by the decisions of the Attorneys General in the cases discussed and attempt to identify some of the key lessons that can be drawn from those episodes.

\section{Background}

\section{A. A Brief History of the Attorney General's Jurisdiction}

The position of Attorney General was created by the Judiciary Act of $1789,{ }^{21}$ which provided for the appointment of a "meet person learned in the law, to act as attorney-general for the United States."22 The Judiciary Act required the Attorney General both to "prosecute and conduct all suits in the Supreme Court in which the United States shall be concerned," as well as to "give his advice and opinion upon questions of law when required by the President of the United States, or when required by the heads of any of the departments." 23 The Judiciary Act also provided for the appointment of "an attorney for the United States" in every district, who would represent the United States in the lower courts. ${ }^{24}$ From the outset, then, the Attorney General has had two main responsibilities: to provide legal opinions to the President and to appear before the Supreme Court on behalf of the United States.

Initially, the Attorney General was a part-time, almost contract, position. He received a salary, but was given neither an office nor any funds with which to hire a staff or cover any expenses. ${ }^{25}$ Indeed, he was expected to continue the private practice of law. ${ }^{26}$ The assumption seems to have been that he would be grateful for the post, as it

20. 11 U.S. (7 Cranch) 32 (1812).

21. An Act to Establish the Judicial Courts of the United States, ch. 20, 1 Stat. 73 (1789).

22. Id. § 35 .

23. Id.

24. Id.

25. Luther Huston, The Department of Justice 9 (1967).

26. Id. 
would boost his prestige with his private clients. ${ }^{27}$ There seemed to be no concern over any potential conflicts of interest.

Demands were first made for the creation of a law department as far back as the Jackson Administration. President Polk, in 1845, and President Pierce, in 1854, made similar proposals. ${ }^{28}$ One of the primary arguments for creating a law department was to remedy the haphazard assignment of legal functions delegated by Congress to various departments, which often left the Attorney General's role ambiguous. For example, under the Judiciary Act, the Attorney General had no authority over the attorneys for the United States in the various districts. ${ }^{29}$ Instead, the Agent of the Treasury, who was not a lawyer, was responsible for supervising those attorneys in litigation to recover money owed to the federal government. ${ }^{30}$ The Agent of the Treasury in fact asked the Attorney General for legal opinions, although the Agent remained subordinate to the Secretary of the Treasury. ${ }^{31}$ It was not until 1870 that a law department was finally created, with the establishment of the Department of Justice, which placed many of the government's attorneys under the Attorney General's direct control and clarified the relationship between the various cabinet officials. ${ }^{32}$

Throughout the development of the Attorney General's office, though, and no matter the scope of that office's jurisdiction, the core functions of the Attorney General remain the same to this day as they were in 1789. The Attorney General is still responsible for providing the President with legal opinions and, while the practical elements of this role were transferred to the Solicitor General in 1870, the Attorney General is still responsible for supervising the representation of the United States government before the Supreme Court. ${ }^{33}$ In the latter function, the Attorney General has, on many occasions, refused to argue the government's case. The reasons for, and results of, those refusals are numerous and will be discussed below.

27. Id. The first Attorney General to quit private practice and devote himself full time to the position was Caleb Cushing in 1853. Id. at 11 .

28. For an overview of the various proposals, see $i d$. at 12-15.

29. Daniel J. Meador, The President, The Attorney General, and the Department of Justice $6-7$ (1980).

30. Id. at 7 .

31. Cummings \& MacFarland, supra note 12 , at $82-83$. This practice was ended by Attorney General William Wirt in 1817. Id.

32. See infra text accompanying notes 201-11.

33. See 28 U.S.C. $\$ 519$ (2006). 


\section{B. The Duty to Defend and Conventional Exceptions}

It is almost universally accepted that there are some situations in which it is appropriate for the executive to refuse to enforce or defend an act of Congress. ${ }^{34}$ The concept goes back at least as far as James Wilson's statement to the Pennsylvania convention on the adoption of the federal Constitution, where Wilson observed:

$[\mathrm{I}] \mathrm{t}$ is possible that the legislature . . may transgress the bounds assigned to it [by the Constitution], and an act may pass, in the usual mode, notwithstanding that transgression; but when it comes to be discussed before the judges,- - when they consider its principles, and find it to be incompatible with the superior power of the Constitution,-it is their duty to pronounce it void . . . In the same manner, the President of the United States could shield himself, and refuse to carry into effect an act that violates the Constitution. ${ }^{35}$

More recently, the other branches of the government have reaffirmed this basic concept. In 1979, Congress adopted a statute requiring that the Attorney General notify Congress any time he refuses to enforce or defend a law, thus tacitly approving of the practice. ${ }^{36}$ Similarly, though the Supreme Court has consistently held that its own power to invalidate an act of Congress as unconstitutional is "one of great delicacy, and only to be performed where the repugnancy is clear, and the conflict irreconcilable," 37 the Court has nonetheless declared that it might be appropriate for the President to "disregard

34. This Article will focus specifically on the decision of the executive not to defend an act of Congress. However, much of the commentary on the subject has focused on a president's refusal to enforce certain statutes, or provisions of statutes. See infra notes 35-39 and accompanying text. Broadly speaking, when faced with a potentially unconstitutional statute, the President has several options: (1) he can enforce the statute and defend it against challenges in the courts; (2) he can continue to enforce the statute, but refuse to defend it; or (3) he can refuse to enforce or defend the statute. See infra Part I.B. The two issues necessarily overlap and insight into the one can be gleaned from the other.

35. James Wilson, Statement before the Convention of the State of Pennsylvania (Dec. 1, 1787), reprinted in 2 Debates in the Several State Conventions on the Adoption of the Federal Constitution 446 (Jonathan Elliot ed., 1836) (emphasis added).

36. Department of Justice Appropriation Authorization Act, Fiscal Year 1980, Pub. L. No. 96-132, §21 (a), 93 Stat. 1049, 1049-50 (1979) ("The Attorney General shall . . . transmit a report to each House of the Congress in any case in which the Attorney General . . . determines that the Department of Justice ... will refrain from defending any provision of law enacted by the Congress in any proceeding before any court of the United States ....").

37. Mayor v. Cooper, 73 U.S. (6 Wall.) 247, 251 (1867); see also Heart of Atlanta Motel, Inc. v. United States, 85 S. Ct.1, 2 (1964) (describing the "judicial power to hold [an] act unconstitutional [as] an awesome responsibility calling for the utmost circumspection in its exercise"). 
[acts of Congress] when they are unconstitutional." 38 The reason a President can legitimately refuse to obey an unconstitutional law is, in a sense, self-evident: laws that are enacted contrary to the Constitution are not "the supreme law of the land. They are merely acts of usurpation and ... deserve to be treated as such." 39

Conventional doctrine holds that the executive can properly refuse to defend an act of Congress in one of three situations: (1) where the act infringes on the rights of the executive, in violation of the separation of powers doctrine; (2) where a statute is so patently unconstitutional that there is no serious argument that can be made for its constitutionality; and (3) where the President believes, upon an individual assessment, that the law is unconstitutional. The third of these exceptions to the executive's general duty to defend acts of Congress in court is both the most controversial and the least discussed. Its apparent origins in the conflict over the Reconstruction Acts, most notably in Ex Parte McCardle, will be the main focus of this Article. However, a brief overview of the less contentious exceptions is first necessary.

\section{The Separation of Powers Exception}

The most common and least objectionable justification given by Attorneys General who refuse to defend statutes concerns statutes the executive believes infringe upon the inherent powers of the Presidency. This exception appears to have been a caveat to even the earliest Attorney General opinions on the duty of the President to execute laws passed by Congress. ${ }^{40}$ As Attorney General Black noted, "Congress is vested with legislative power; the authority of the President is executive. Neither has the right to interfere with the functions of the other." ${ }_{11}$ The general proposition that the executive has the right to refuse to defend or enforce a statute that infringes on executive power

38. Freytag v. Commissioner, 501 U.S. 868, 906 (1996) (Scalia, J., concurring in part and concurring in the judgment); see also Youngstown Sheet \& Tube Co. v. Sawyer, 343 U.S. 579, 637 (1952) (Jackson, J., concurring) (recognizing that the President might legitimately take "measures incompatible with the expressed or implied will of Congress," but that his power to do so is at its "lowest ebb"). But see Kendall v. United States, 37 U.S. (12 Pet.) 524, 525 (1838) ("To contend that the obligations imposed on the President to see the laws faithfully executed, implies a power to forbid their execution; is a novel construction of the constitution, and is entirely inadmissible.").

39. The Federalist No. 33, at 188 (Alexander Hamilton) (Garry Wills ed., 1982).

40. See 9 Op. Att'y Gen. 462, 468 (1860) ("Congress could not, if it would, take away from the President, or in anywise diminish the authority conferred upon him by the Constitution.").

41. Id. at 469 . 
has been consistently reaffirmed by commentators and Attorneys General to the point that "almost all of the legal authority" on the decision not to defend statutes arises out of "situations where the Acts themselves touch on constitutional separation of power between Executive and Legislative Branches." 42

One of the earliest of these cases was Myers $v$. United States, ${ }^{43}$ argued and decided during the Wilson Administration. In Myers, Congress had passed a statute requiring the advice of the Senate for the removal of "postmasters of the first, second, and third class." 44 Myers was a first class postmaster who had been removed by the Postmaster General at the direction of the President, but without the consent of the Senate. ${ }^{45}$ When Myers brought suit, the Solicitor General appeared before the Supreme Court on behalf of the United States, but argued against the statute. ${ }^{46}$ Responsibility for defending the statute instead fell to former Senator George Wharton Pepper, who had been appointed by the Court to defend the interests of Congress. ${ }^{47}$ When rising to address the Court, the attorney for the Postmaster observed:

In the 136 years that have passed since the Constitution was adopted, there has come before this Court for the first time, so far as I am able to determine, a case in which the Government, through the Department of Justice, questions the constitutionality of its own act. As to that, I have no criticism to offer; I think it is but proper. We find the Solicitor General appearing as a representative of the Executive Department of the Government. And we have Senator Pepper, as amicus curiae, who, as I take it from his brief, represents another branch, the Legislative branch, of the Government. I appear as counsel for the appellant, who brought this suit in the first instance. It is gratifying to feel that all interests are properly represented. ${ }^{48}$

42. 4A Op. O.L.C. 55, 56 (1980). See also 31 Op. Att'y Gen. 475, 476 (1919) (stating that "it is not within the province of the Attorney General to declare an Act of Congress unconstitutional" except where the statute presents a "conflict between the prerogatives of the legislative department and those of the executive department"); Days, supra note 12, at 499 ("Solicitors General have always sided with the President in disputes over the constitutionality of congressional attempts to circumscribe presidential power."); Dellinger, supra note 12, at 315 ("The President has enhanced responsibility to resist unconstitutional provisions that encroach upon the constitutional powers of the Presidency."); Waxman, supra note 12, at 1084 (recognizing an exception to the duty to defend where "an Act of Congress raises separation of powers concerns").

43. 272 U.S. 52 (1926).

44. Id. at 86 .

45. Id. at 106

46. See Dalena Marcott, The Duty to Defend: What is in the Best Interests of the World's Most Powerful Client?, 92 GeO. L.J. 1311, 1329 (2004).

47. Id.

48. Myers, 272 U.S. at 57. 
The Myers Court ultimately ruled in favor of the administration, finding that the statute unconstitutionally infringed upon the President's powers. ${ }^{49}$ Yet, the Court stressed that Pepper's appearance had been essential in "enabling the Court to satisfy itself that it has fully considered all that can be said." 50

A more recent example of the separation of powers exception was the Reagan-era case of INS v. Chadha. ${ }^{51}$ In Chadha, Congress had passed a statute "authorizing one House of Congress, by resolution, to invalidate the decision of the Executive Branch, pursuant to authority delegated by Congress to the Attorney General of the United States, to allow a particular deportable alien to remain in the United States." ${ }^{2}$ Similar to Myers, the Solicitor General, Rex Lee, appeared on behalf of the Immigration and Naturalization Service, but not on behalf of the Immigration and Nationality Act. ${ }^{53}$ Instead, the Act was defended by separate counsel, Michael Davidson, who represented the Senate, and Eugene Gressman, who appeared on behalf of the House. ${ }^{54}$ The Court considered the argument that that it lacked jurisdiction because "Chadha and the INS take the same position on the constitutionality of the one-House veto" and that this fact meant that there was no "controversy" for the Court to decide. ${ }^{55}$ The Court disagreed, observing, "it would be a curious result if, in the administration of justice, a person could be denied access to the courts because the Attorney General of the United States agreed with the legal arguments asserted by the individual." 56

Myers and Chadha provide two clear examples of congressional statutes in tension with the executive power that the executive has,

49. Myers v. United States, 272 U.S. 52, 176 (1926) ("[W]e must therefore hold that the provision of the law of 1876 , by which the unrestricted power of removal of first class postmasters is denied to the President is in violation of the Constitution, and invalid.").

50. Id. at $176-77$.

51. 462 U.S. 919 (1983).

52. Id. at 923. The specific facts of the case are not relevant here, but for an exhaustive exploration of them, see Barbara H. Craig, Chadha: The Story of an Epic ConstituTiONAL StrugGle (1988).

53. See Chadha, 462 U.S. at 921.

54. See id. at 922 .

55. Id. at 939 .

56. Id. Nonetheless, the Court found the formal intervention of Congress in the case to mean that "concrete adverseness is beyond doubt." Id. A controversy also existed because the INS would have complied with the law if the Court had held it to be constitutional. See id. at 939-40 ("We agree with the Court of Appeals that Chadha has asserted a concrete controversy, and our decision will have real meaning: if we rule for Chadha, he will not be deported; if we uphold 244(c)(2), the INS will execute its order and deport him." (internal quotations and citations omitted)). 
accordingly, declined to defend. ${ }^{57}$ These cases present fairly benign examples of situations in which the executive has non-controversially declined to defend acts of Congress holding separation of powers implications. Indeed, an executive defense in these situations may have been somewhat suspect. There are many other examples of the executive refusing to defend or, as in Myers and Chadha, actively arguing against an Act of Congress. ${ }^{58}$ The facts of the individual cases vary, but in no case does the Court's opinion suggest a problem with the executive's refusal. ${ }^{59}$ Indeed, there does not seem to be much objection from any quarter to the limited practice of executive refusal to defend statutes that raise separation of powers issues. ${ }^{60}$

\section{The Patent Unconstitutionality Exception}

The second exception to the duty to defend concerns situations in which the Attorney General believes a statute to be patently unconstitutional, i.e., when no professionally responsible argument can be made in defense of the statute. This exception can be phrased in a number of ways. It might be construed very narrowly as a situation in which "defending the statute would require [asking] the Supreme Court to overrule one of its constitutional precedents." 1 More broadly, it can be portrayed as applying to situations in which "the Attorney General believes, not only personally as a matter of conscience, but also in his official capacity as the Chief Legal Officer of the United States, that a law is so patently unconstitutional that it cannot be defended." ${ }^{62}$ Federal Judge Frank Easterbrook mockingly described the standard this way:

One stream of argument some solicitors general have accepted is that statutes should be defended if you can make an argument in their favor without breaking out laughing. It is the risibility test for

57. In Myers, Congress sought to restrict the President's ability to terminate his staff. Myers v. United States, 272 U.S. 52, 107-08 (1926). In Chadha, it was a legislative attempt to override an executive decision. See generally Chadha, 462 U.S. at 919.

58. For a list of some additional examples, see Days, supra note 12, at 499 n.70.

59. The lack of comment on the executive's action in Myers has been cited as marking "significant judicial approval" for that branch's ability to refuse to defend or enforce a statute. Dellinger, supra note 12, at 313 .

60. For an example of such criticism, see James W. Cobb, Note, By "Complicated and Indirect" Means: Congressional Defense of Statutes and the Separation of Powers, 73 GEO. Wash. L. REv. 205, 208 (2004) (arguing that allowing Congress to defend statutes "violates our constitutionally mandated separation of powers").

61. Waxman, supra note 12 , at 1085 .

62. Representation of Congress and Congressional Interests in Court: Hearings Before the Subcomm. on Separation of Powers of the Senate Comm. on the Judiciary, 94th Cong. 9 (1975) (statement of Rex Lee). 
a constitutional defense. If trying to state the defense of the statute does not have you rolling in the aisles, you should defend the statute. ${ }^{63}$

This exception most makes sense in situations where intervening judicial precedents render a statutory provision unconstitutional that "the legislature and the Executive might have considered constitutional at the time of enactment." 64 It is also appropriate in cases where the Court's practice of only ruling on the case in front of it leaves the constitutionality of a similar statute suspect as a result of the Court's decision. ${ }^{65}$ However, almost every decision not to defend a law can conceivably claim justification under the murky "patently unconstitutional" standard and, indeed, such has become the dominant practice. ${ }^{66}$ Unless the standard is read so narrowly as to apply only in situations where there is a direct precedent on point, the exception risks becoming so great as to entirely consume the rule. This exception does not appear to have been addressed by the courts and, indeed, the distinction between this exception and the "independent assessment" discussed below is, by no means, universally accepted. Nevertheless, "patent unconstitutionality" must remain an available exception, for while no two fact patterns are identical, facts are often similar enough to render defenses functionally estopped. This Article draws a distinction between "patent unconstitutionality" and an "inde-

63. Rex E. Lee Conference on the Office of the Solicitor General of the United States: Pre-Reagan Panel, 2003 BYU L. REv. 1, 31 (2003) (statement of Frank Easterbrook) [hereinafter Rex E. Lee Transcript].

64. Waxman, supra note 12, at 1086; see also Rex E. Lee Transcript, supra note 63, at 30 (" $[\mathrm{I}] \mathrm{t}$ was common [for the Solicitor General] not to defend . . . provisions essentially identical to something that had been held unconstitutional.").

65. The Supreme Court has generally refused to give "an advisory opinion upon a hypothetical basis" and rather limits itself to an "adjudication of present right upon established facts." Aetna Life Ins. Co. v. Haworth, 300 U.S. 227, 242 (1937). As a result, a statute is rendered constitutionally suspect, but not explicitly struck down, whenever a separate, but substantively similar, statute is declared invalid by the Court. It would be wasteful to defend such a statute, as the outcome is essentially predetermined.

66. Both the Reagan Administration's decision in League of Women Voters and the Obama Administration's decision regarding the Defense of Marriage Act were justified in terms of "patent unconstitutionality." They were both, correctly, criticized by their opponents who could easily conceive of arguments in defense of the statutes. See Cornell Clayton, The Politics of Justice: The Attorney General and the Making of Legal Policy 197 (1992) (criticizing the decision in League of Women Voters because "there were powerful arguments made by members of Congress and by attorneys within the Justice Department itself supporting the statute"); Defending Marriage: Hearing Before the Subcomm. on the Constitution of the H. Comm. on the Judiciary, 112th Cong. 57-60 (2011) (statement of Edward Whelan) (arguing that Attorney General Holder's claim to have "acted consistently" with the standard is "clearly wrong" since "any competent lawyer could present plenty of reasonable arguments" in defense of the statute). 
pendent assessment of unconstitutionality," where the executive engages in its own review of the statute and comes to a decision about it. Given the separation of responsibilities between the executive and the judiciary, this latter approach is substantially more controversial.

\section{The Independent Assessment of Unconstitutionality Exception}

In cases where the patent unconstitutionality exception is read so narrowly as to become inapplicable, there exists a third, highly controversial exception: situations in which the President or the Attorney General conclude that the statute, while theoretically defensible, is unconstitutional, even absent judicial precedent on point. Some commentators recognize this category as distinct from the previous two, while others attempt to shoehorn it into the "patently unconstitutional" exception. ${ }^{67}$ This third exception is often viewed as a recent jurisprudential development. ${ }^{68}$ In truth, it is a long-standing practice, the origin of which appears to be founded in Ex Parte McCardle. These cases will constitute the remainder of the discussion in this Article, beginning with the well-known Marbury $v$. Madison ${ }^{69}$ and culminating in an in-depth discussion of the slightly less famous Ex Parte McCardle.

\section{Independent Refusals to Defend}

\section{A. The Early Cases}

The earliest cases in which an Attorney General refused to appear on behalf of the government were Marbury $v$. Madison and Hudson $\mathcal{E}^{\circ}$ Goodwin. Strictly speaking, neither of those cases involved an executive decision not to defend an act of Congress. However, they are worth mentioning, if only briefly, as illustrations of the tensions that exist when a case involving the United States is properly brought before the Court and the executive unilaterally refuses to defend. They also illustrate the danger of allowing the Attorney General to exercise such a practice without providing other parties the ability to represent the United States.

67. Compare Waxman, supra note 12, at 1083 (“[E]ven when neither exception applies, the Department of Justice has occasionally declined to make professionally respectable arguments, even when available, to defend a statute-typically, in cases in which . . the President has concluded that the statute is unconstitutional"), with 4A Op. O.L.C. 55, 55 (1980) (arguing that the Attorney General "must examine the Acts of Congress and the Constitution and determine what they require of him; and if he finds in a given case that there is a conflict between the requirements of one and the requirements of the other, he must acknowledge his dilemma and decide how to deal with it").

68. See supra note 19 and accompanying text.

69. 5 U.S. (1 Cranch.) 137 (1803). 
In Marbury, William Marbury-appointed justice of the peace by the outgoing Adams administration-applied to the Court for a writ of mandamus requiring new Secretary of State, James Madison, to deliver Marbury's commission; an act the new administration refused to perform. ${ }^{70}$ James Madison was nominally represented by Attorney General Levi Lincoln. However, when the case was called, Lincoln declined to make an appearance, instead announcing "he had no instructions on the subject, [and] thus [was] leaving the proceedings to the discretion of the justices." ${ }^{1}$ Instead, the trial was run by Charles Lee, counsel to plaintiff William Marbury. ${ }^{72}$ Lincoln was subpoenaed by the Court and initially refused to make any response at all. ${ }^{73}$ Eventually, Lincoln requested that he receive the questions in writing and be afforded time to decide whether to respond. ${ }^{74}$ Madison himself refused to appear and no attorney was present to represent him, nor was any argument made on behalf of the government as to why a writ should not be entered. ${ }^{75}$

Hudson $\mathcal{E}$ Goodwin involved a federal common law prosecution of a pair of newspaper publishers for seditious libel. ${ }^{76}$ The case came before the Supreme Court following a split in the circuit courts regarding whether the federal courts had jurisdiction over common law crimes. ${ }^{77}$ When the case came before the Court, neither Attorney General William Pinkney nor counsel for the defense made an appearance. ${ }^{78}$ It is likely that Pinkney was instructed not to appear on

70. Id. at 138

71. Richard Ellis, The Jeffersonian Crisis: Courts and Politics in the Young RePUBLIC 43 (1971).

72. Id

73. Marbury, 5 U.S. (1 Cranch.) at 144.

74. Id. Although Lincoln was Attorney General at the time, he was subpoenaed because he had previously been Secretary of State and was being called upon to explain what had happened to Marbury's commission; a question that Lincoln refused to answer. See Robert L. Clinton, Marbury v. Madison and Judicial Review 83 (1989). Thus, the proceedings before the Court in Marbury were entirely non-adversarial.

75. Id. at 85 .

76. United States v. Hudson \& Goodwin, 11 U.S. (7 Cranch) 32, 32 (1812). Hudson and Goodwin published a newspaper which had printed an article claiming that Congress had spent two million dollars to bribe Napoleon, at the request of President Jefferson. See William W. Crosskey, 2 Politics and the Constitution in the History of the United STATES 767-84 (1953).

77. Thus, like Marbury, Hudson $\mathcal{E}$ Goodwin did not deal with an act of Congress. In truth, that case represented a conflict between the executive and the judiciary. See Hudson E Goodwin, 11 U.S. (7 Cranch) at 32.

78. Id. ("Pinkney, Attorney General, in behalf of the United States, and Dana for the Defendants, declined arguing the case."). 
the orders of President Madison ${ }^{79}$ - who opposed federal common law jurisdiction-as Pinkney himself was a well-known proponent of federal common law. ${ }^{80}$ Regardless of his personal opinion, however, Pinkney did not appear and the Court issued its opinion holding that federal courts had no jurisdiction over common law crimes. ${ }^{81}$

Justice William Johnson, who delivered the Court's opinion in that case, later suggested that the "true reason" Hudson $\mathcal{E}^{\circ}$ Goodwin was not argued was "the universal opinion prevailing at the bar, that opinion had ... settled down against it." 82 Some have suggested that Pinkney's lack of argument supports the claim that the Court's decision merely formally adopted a preexisting consensus. ${ }^{83}$ On the other hand, it is almost certain that a number of the justices-as many as three of the seven members of the Court-openly held the belief that there was federal common law jurisdiction. ${ }^{84}$ Thus, the opinion was arguably not as "universal" as it might seem. Perhaps the unanimity decision was less an agreement on the issue, so much as it was a submission to the political reality of the inevitable result. ${ }^{85}$ Regardless, with neither counsel appearing to offer an argument, the Supreme Court found itself rendering an opinion that seemed to rest less on legal principles than on "public opinion." 86

79. See Robert Ireland, The Legal Career of William Pinkney 91 (1986) ("President Madison doubtlessly directed Pinkney not to argue the case ....").

80. Henry Wheaton, Some Account of the Life, Writings, and Speeches of WilLiam Pinkney 114 (New York, Collins \& Co. 1826) ("I am told that Mr. Pinkney had formed, and frequently, expressed, a very decided opinion that the courts of the Union possessed a common law jurisdiction ...."). Indeed, Pinkney had corresponded with then Supreme Court Justice Story regarding the importance of passing legislation that would grant "the Courts of the U.S. a common law jurisdiction as to crimes." Letter from Supreme Court Justice Joseph Story to Attorney General William Pinkney (June 26, 1812), reprinted in Gary D. Rowe, The Sound of Silence: United States v. Hudson \& Goodwin, the Jeffersonian Ascendency, and the Abolition of Federal Common Law Crimes, 101 YALE L.J. 919, 926 (1992).

81. Hudson $\mathcal{E}$ Goodwin, 11 U.S. (7 Cranch) at 34.

82. R. Crush, Trial of William Butler for Piracy 12 (1813).

83. See, e.g., Rowe, supra note 80 , at 926 ("By choosing not to argue the case, Pinkney appears to have recognized that his position was outside the new constitutional consensus that had emerged by the time Hudson reached the Supreme Court.").

84. For a discussion of the justices' votes, see Phillip Blumberg, Repressive Jurisprudence in the Early American Republic 183 (2010).

85. See Gerald T. Dunne, Joseph Story: 1812 Overture, 77 Harv. L. Rev. 240, 244 (1963) ("Dismissal of the charge by the new Republican Supreme Court was virtually preordained."); BlumBERG, supra note 84, at 183-84 ("In rejecting the concept of federal criminal common-law jurisdiction, the Supreme Court was only ratifying what had become the new reality at the polls.").

86. United States v. Hudson \& Goodwin, 11 U.S. (7 Cranch) 32, 32 (1812) ("Although this question is brought up now for the first time to be decided by this Court, we 
Four years later, after the machinations of Justice Story, the issue was re-presented to the Court in United States v. Coolidge. ${ }^{87}$ The new Attorney General, Richard Rush, once again refused to argue the case. ${ }^{88}$ In effect, his refusal was sufficient to uphold the Court's prior decision in Hudson $\mathcal{E}$ Goodwin, with Justice Johnson indicating support for the previous holding, Justice Story expressing his opposition, and Justices Washington and Livingston indicating that they were willing to rehear the question, but only if "counsel can be found ready to argue it." 89

Hudson $\mathcal{E}^{2}$ Goodwin presents an interesting prologue to the question of the Attorney General's duty to defend acts of Congress. Here was a situation where, in a case, "instituted on behalf of the United States for a crime allegedly committed against the government, the Attorney General of the United States ... refused to appear to argue on behalf of the constitutionality of the prosecution that ... he had previously supported." ${ }^{90}$ More troubling was the ability of Attorney General Rush to prevent a constitutional issue from being heard before the Supreme Court, simply by refusing to appear in Coolidge. Here, unlike the cases discussed next, there was no obvious available party to intervene. While arguments can be made for allowing a branch of government to defend itself against another branch, it is less clear that it is appropriate for an administration to refuse to appear because it opposes a law as a matter of politics.

\section{B. Ex Parte McCardle}

\section{The Reconstruction Acts of $\mathbf{1 8 6 7}$}

After the American Civil War, beginning in March 1867, Congress passed four statutes collectively known as the Reconstruction Acts of $1867 .{ }^{91}$ The statutes were enacted over the veto of President Andrew Johnson, who had also vetoed several other Reconstruction Era statutes up to that point. ${ }^{92}$ Among other things, the first of the

consider it as having been long since settled in public opinion.”).

87. 14 U.S. (14 Wheat.) 415 (1816).

88. Id. at $415-16$.

89. Id. at 416 .

90. Blumberg, supra note 84 , at 182.

91. Act of Mar. 11, 1868, ch. 25, 15 Stat. 41 (1868); Act of Mar. 2, 1867, ch. 153, 14 Stat. 428 (1867); Act of Mar. 23, 1867, ch. 6, 15 Stat. 2 (1867); Act of July 19, 1867, ch. 30, 15 Stat. 14 (1867).

92. See Eric Foner, Reconstruction: America's Unfinished Revolution 247-51 (1988). 
Acts divided the "rebel states" into five military districts ${ }^{93}$ and directed the President to appoint "an officer of the army, not below the rank of brigadier-general," to command each district. ${ }^{94}$ The Acts further granted to the military commander of each district the power to "protect all persons in their rights of person and property, to suppress insurrection, disorder, and violence, and to punish . . . all disturbers of the public peace and criminals." 95 To that end, the military commander was to "organize military commissions or tribunals" for the purpose of punishing the offenders. ${ }^{96}$ The Acts provided for a convention to be called in order to create a new government for each of the recently conquered states and to adopt new state constitutions that were amenable to the federal Congress. ${ }^{97}$ It provided that the delegates to this convention were to be elected from "male citizens of said State, twenty-one years old and upward, of whatever race, color, or previous condition, who have been resident of said State for one year previous to the election, except such as may be disfranchised for participation in the rebellion." 98 This final provision, the exclusion of those who had participated in "the rebellion," served to effectively disfranchise all southern whites and create a convention that would be almost entirely made up of newly enfranchised blacks, as well as recent arrivals to the South from the North-the so-called "carpetbaggers." 99

In his veto message, substantially written by legendary lawyer and former Chief Justice of Pennsylvania, Attorney General and Secretary of State, Jeremiah S. Black, together with Attorney General Henry Stanbery, ${ }^{100}$ Andrew Johnson echoed many of the same concerns regarding the disfranchisement. His primary objection, however, was the imposition of military rule on the southern states. The veto message propounded upon the unconstitutionality of the Act, enumerating the constitutional rights that had been stripped from the citizenry of the southern states by the establishment of the military commissions:

93. Preamble, 14 Stat. at 428.

94. Id. $\$ 2$.

95. Id. $\S 3$.

96. $I d$.

97. $\quad I d . \S 5$.

98. Id.

99. Sever Eubank, The McCardle Case 7 (1954); see also Fairman, supra note 17, at 260 (noting that the requirement of "unbroken loyalty" would "include the mass of freedman, but comparatively few Southern whites.").

100. FAIRMAN, supra note 17 , at 307. 
[A]n Act of Congress is proposed which if carried out would deny a trial by the lawful courts and juries to nine million American citizens and their posterity for an indefinite period. It seems scarcely possible that any one should seriously believe this consistent with a Constitution which declares in simple, plain language that all persons should have that right, and that no person shall ever in any case be deprived of it. The Constitution also forbids the arrest of the citizen without judicial warrant, founded on probable cause. This bill authorizes arrest without warrant at the pleasure of a military commander. ${ }^{101}$

The message asserted that the obligation of the federal government to provide the states with a republican form of government could not possibly be met with the passage of an act which "wipes away ever $[s i c]$ vestige of republican government ... and puts the life, property, liberty and honor of all the people [in the southern states] under the domination of a single person clothed with unlimited authority[.]"102 In a particularly strong passage, the message raged:

Those who advocated the right of secession alleged in their own justification that we had no regard for law, and that their rights of property, life, and liberty would not be safe under the Constitution as administered by us. If we now verify their assertion, we prove that they were in truth and in fact fighting for their liberty, and instead of branding their leaders with the dishonoring name of traitors against a righteous and legal Government, we elevate them in history to the rank of self-sacrificing patriots [and] consecrate them to the admiration of the world . . . . ${ }^{103}$

Nevertheless, the House and Senate quickly overcame the veto and the bill became law. Shortly thereafter, the President and Attorney General's objection to the constitutionality of the Act would lead to one of the more interesting legal dramas of the period.

\section{The Arrest of William McCardle for Impeding Reconstruction}

William McCardle was a Vicksburg newspaperman. ${ }^{104}$ Beginning in the $1850 \mathrm{~s}$, McCardle became a strong proponent of states' rights and left the newspaper to join the Confederate Army when the war broke out. ${ }^{105}$ After the war, McCardle became editor of the Vicksburg Times, which had recently been established as a post-war platform for states' rights arguments. ${ }^{106}$ As editor of one of the most popular news-

101. Cong. Globe, 39th Cong., 2d Sess. 1971 (1867).

102. Id.

103. Id.

104. Eubank, supra note 99, at 11.

105. Id. at 12-13.

106. Id. at 13 . 
papers in Mississippi, McCardle found himself embroiled in the conflict between the southern states and the military reconstruction.

In March 1867, General Edward Ord was given command of the Fourth Military District ${ }^{107}$ and instructed to organize the constitutional convention required by the Reconstruction Acts. ${ }^{108}$ Despite his role as military commander, Ord was fairly well regarded by the residents of Mississippi. ${ }^{109}$ Ord began by creating a board of registrars for each county, but the requirement that no registrar have fought against the Union meant that they were "for the most part freedman, military officers, and ex-Union soldiers who had settled in the state since the close of the war." 110

Many white residents of Mississippi found this process intolerable and "declared that the state was no longer a fit habitation for white men." 111 Chief among the critics was McCardle, who published a series of scathing editorials attacking Ord, the convention, and military rule. He described the military commanders as "infamous, cowardly, and abandoned villains." 112 More disruptively, McCardle encouraged white voters to boycott the convention and threatened recourse against those who voted in it. After his case gained national attention, the New York Times published key excerpts of McCardle's editorials:

Stay Away from the Polls.-We again urge every decent white man, every honorable gentleman of the Caucasian race, to avoid Gen. Ord's election as he would avoid pestilence and a prison. As this advice does not apply to and is not intended for the white snakes of the Loyal League, we shall expect the last-named despicable vermin out in all their strength . . .

The Immortal Fight. - We are gratified to be able to announce to the readers of the Times that at the Court-house yesterday, the only place open to the whole people, there were cast the votes of eight white people only! We tried to get the names of the interesting sneaks who voted, but failed, though the Times office was and is ready to pay a dollar for the name of each voter. We shall publish the names of these voters if we can obtain them, and some day we shall; but if we do not, we shall with pride chronicle the fact that in

\footnotetext{
107. James W. Garner, Reconstruction in Mississippi 161 (1901).

108. Id. at 171 .

109. Id. at 161-62.

110. Id. at 172 .

111. Id. at 175 .

112. William W. Van Alstyne, A Critical Guide to Ex Parte McCardle, 15 ArIz. L. Rev. 229, 236 n.42 (1973).
} 
the heroic city of Vicksburg, . . . there were only eight cowards, dogs, and scoundrels of the Nygatt and McKee stripe. ${ }^{113}$

On November 8, 1867, Ord had McCardle arrested. ${ }^{114}$ McCardle was to be tried before a military commission on four charges: (1) disturbance of the public peace; (2) inciting insurrection, disorder, and violence; (3) libel, for the pieces he had written against Ord personally; and (4) "impeding reconstruction" for his editorials encouraging white voters not to vote for delegates to the convention. ${ }^{115}$

On November 11, counsel for McCardle sought a writ of habeas corpus before the United States District Judge at the federal court in Jackson, Mississippi, claiming that McCardle's "arrest and detention is in contravention of the Constitution and laws of the United States."116 Judge Hill issued the writ on November 21, and held a three-day hearing on the issue. ${ }^{117}$ On November 25, Judge Hill issued his opinion ruling against McCardle, but also granting \$2000 bail pending appeal. ${ }^{118}$ In that opinion, after tracing the history of the Reconstruction Acts, Judge Hill drew an analogy between tribunals that had been created by the provisional Governors at the direction of the President and the military commissions authorized by Congress. ${ }^{119}$ Noting that the judicial tribunals established by the Provisional Governor arose not "by means of any express provision of the Constitution, but ... out of the necessity of the condition of the State," Judge Hill noted that he was unable to draw a distinction between the Governor's exercise of that power, as authorized by the President, and the exercise of the same power by the military commander, as authorized by Congress. ${ }^{120}$ " $[\mathrm{I}] \mathrm{f}$ it is the duty of the government of the United States . . to pro-

113. Reconstruction: A Test Case in the United States Supreme Court-The Opposition to the Laws in Mississippi-An Irate Editor on the Officers and Operations of the Freedmen's Bureau, N.Y. Times, Jan. 14, 1868, at 2 [hereinafter A Test Case in the United States Supreme Court].

114. FAIRMAN, supra note 17 , at 437 .

115. Id. at 437-38.

116. Id. at 438 .

117. $I d$.

118. Id. Judge Hill's opinion was not reported in the Federal Reporter, but was widely reproduced in newspapers.

119. Shortly after taking office, President Johnson appointed Provisional Governors in the Confederate States and created tribunals to put "the laws of the United States into operation.” John Savage, The Life and Public Services of Andrew Johnson 373-75 (1866). The authority of these tribunals had been challenged in the state courts in Scott v. Billgerry, 40 Miss. 119 (1866). The High Court of Errors and Appeals of Mississippi held that the tribunals were federal in nature; arising out of the President's power to create governments "while holding a State under absolute military rule." Id. at 143. The court further held that inherent in this right to create a provisional government was the right to "ordain laws, and to establish judicial tribunals for their administration." Id.

120. A Test Case in the United States Supreme Court, supra note 113, at 2. 
tect the citizens in their rights of person and property" Judge Hill explained, "then the choice of means must be made by the power conferring such authority." ${ }^{121}$ Hill refused to find the Reconstruction Acts unconstitutional. ${ }^{122}$

\section{The Attorney General Refuses to Defend the Reconstruction Acts}

McCardle appealed Judge Hill's decision to the Supreme Court on December 23, 1867.123 On December 31, Attorney General Henry Stanbery wrote to the Acting Secretary of War, Ulysses S. Grant, ${ }^{124}$ to express his intention not to appear in the case:

I beg leave to call your attention to case No. 380 on the calendar of the Supreme Court of the United States for this term, entitled Ex parte McCardle. . . . I do not propose to appear in the case. As the matter appertains to your Department, I will suggest to you the propriety of employing counsel to represent the parties having McCardle in custody, so that the case may receive proper attention before the Supreme Court. ${ }^{125}$

Stanbery's letter prompted a flurry of correspondence from the War Department, discussing new counsel to represent the United States. A telegram was sent to General Ord asking whether "it is advisable to employ the same council [ $s i c$ ] that managed the McCardle Case in Mississippi to appear for the United States in the appeal to the su-

121. Id.

122. Id. At the close of his opinion, Hill also expressed relief that "the law has provided a direct appeal to the Supreme Court . . . where any error I may have committed can be corrected." Id. The Habeas Corpus Act of 1867 had amended the Judiciary Act of 1789 to allow for an appeal of habeas decisions to the Supreme Court. Act of Feb. 5 1867, ch. 28, 14 Stat. 385, 386 (1867).

123. FaIrman, supra note 17 , at 449 .

124. Johnson had removed Stanton and replaced him with General Grant. See ERIC L. McKitrick, Andrew Johnson And Reconstruction 494-99 (1960). This would set in motion Johnson's ultimate blatant violation of the Tenure of Office Act, which would lead to his impeachment. See Edmund Gibson Ross, History of the Impeachment of Andrew Johnson 57-64 (1868). The Tenure of Office Act was ultimately declared unconstitutional in Myers, discussed supra Part I.B.1. Curiously, in calling for the impeachment of Johnson, certain members of Congress argued that "to allow the President the power to violate an act of Congress ... in order to make up an issue before the courts upon the question of its constitutionality, would be virtually to attribute to the President the once hated royal power of suspending the law at the pleasure of the Executive." John W. Burgess, RecONSTRUCTION AND THE Constitution 182 (1902).

125. Letter from Attorney General Henry Stanbery to Secretary of War Ulysses S. Grant (Dec. 31, 1867), in 18 The Papers of Ulysses S. Grant 99 (John Simon, ed., 1991). 
preme court here."126 A few days letter, Grant wrote Senator Lyman Trumbull of Illinois:

The case, exparte $[s i c]$ W.H. McCardle, appealed from the circuit court of So. Dist. of Miss. to the Supreme Court of the United States it is believed may soon be called up. The Attorney General of the United States having expressed his intention not to appear in the case this Department desires to engaged [ sic] your professional services for that object. ${ }^{127}$

On January 11, 1868, Senator Trumbull agreed. ${ }^{128}$ Trumbull was in many ways an obvious choice. He was the chairman of the Senate Judiciary Committee and "[o]ne of the most influential men in Congress." 129 Perhaps more importantly, Trumbull was a moderate who played a key role in the drafting of both the Freedmen's Bureau Bill and the Civil Rights Bill, the first legislative attempt to give meaning to the Thirteenth Amendment. ${ }^{130}$ Trumbull also had played a significant role in justifying Radical Reconstruction, arguing that Congress must "enter these States and hurl from power the disloyal element which controls and governs them."131

Trumbull engaged James Hughes and Senator Matthew Carpenter of Wisconsin as co-counsel. ${ }^{132}$ Writing to Carpenter, Trumbull explained:

I was retained on behalf of the Government by General Grant .... Judge Hughes is also with me, and I am authorized by General Grant and also Mr. Stanton to retain you .... . Please let me hear from you at once, and come on as soon as your convenience will permit. If the validity of the reconstruction acts is to be determined by the decision, it is the most important case ever submitted to a court. ${ }^{133}$

Thus, when the Supreme Court met to hear Jeremiah Black's motion to advance the case, ${ }^{134}$ the United States was represented by a

126. Telegram from General Edmund Schriver to General Edward Ord (Jan. 4, 1868), in 18 The Papers of Ulysses S. Grant 99 (John Simon, ed., 1991).

127. Letter from Secretary of War Ulysses S. Grant to Senator Lyman Trumbull (Jan 8, 1868), in 18 The Papers of Ulysses S. Grant 99 (John Simon, ed., 1991).

128. Letter from Senator Lyman Trumbull to Secretary of War Ulysses S. Grant (Jan 11, 1868), in 18 The Papers of Ulysses S. Grant 99 (John Simon, ed., 1991).

129. FONER, supra note 92, at 243.

130. Id.

131. Id. at 272 .

132. Letter from Senator Lyman Trumbull to Senator Matthew Carpenter (Jan. 22, 1868), reprinted in Cong. GLOBE, 42d Cong., 2d Sess. 1702 (1872).

133. Id.

134. A motion to advance is a motion to expedite the hearing and decision where "the importance of the result to [the appellant is] sufficient to warrant the preference asked for over suitors having prior cases on the docket." McGuire v. Massachusetts, 70 U.S. 382, 384 (1865); see also United States v. Norton, 91 U.S. 558, 558 (1875) (granting the motion to 
sitting senator, rather than a member of the executive branch. ${ }^{135}$ Stanbery was present, however. He explained to the Court that he had previously informed the President that he believed the military commissions were not constitutional and "[t]his being his opinion, he could not, of course, take the other side of the question."136 This left Jeremiah Black and Lyman Trumbull to debate whether the case should be advanced. On January 21, Chief Justice Chase declared, with a majority of the Court concurring, that the case would be advanced. ${ }^{137}$ For his part, McCardle was thrilled. The day following the Court's announcement, the Vicksburg Daily Times reported:

When it comes up, the whole question of the validity of the reconstruction acts will be ably and elaborately argued, and the question of the Constitutionality of the acts will be finally put to rest. The decision of the highest tribunal known to our laws will be looked for with the deepest interest ... The lives and liberties of the whole people are involved, for the decision of the Court will determine whether ours in [sic] a government of Law or a naked military despotism. ${ }^{138}$

\section{Reactions to Stanbery's Decision}

Stanbery's decision not to appear caused a good deal of controversy. This was not the first time that Stanbery had refused to argue a position before the Court. In Ex Parte Milligan, ${ }^{139}$ two years earlier, Stanbery had appeared along with Attorney General James Speed and Benjamin F. Butler. ${ }^{140}$ However, Stanbery appeared only to argue that the Supreme Court did not have jurisdiction over the appeal under the Judiciary Act of 1802. ${ }^{141}$ Specifically, Stanbery argued that an ex parte action was not yet a "cause" that could be appealed under the relevant portion of the Judiciary Act and, therefore, the Court lacked jurisdiction over ex parte habeas petitions. ${ }^{142}$ The Court rejected this

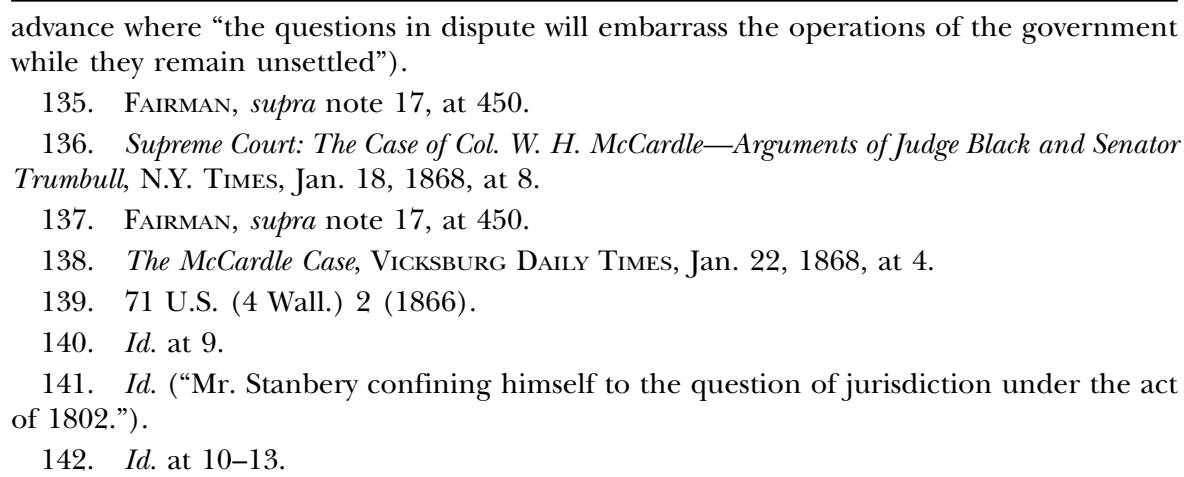


argument, holding that "[i]n any legal sense, action, suit, and cause, are convertible terms." 143

Similarly, very shortly before refusing to appear in McCardle, Stanbery had appeared on behalf of the government in Georgia v. Stanton, ${ }^{144}$ a case involving the very Reconstruction Acts at issue in McCardle. ${ }^{145}$ In that case, the State of Georgia argued that the Reconstruction Acts served to

overthrow and to annul this existing State government, and to erect another and different government in its place, unauthorized by the Constitution and in defiance of its guarantees; and that, in furtherance of this intent and design, the defendants . . . acting under orders of the President, were about setting in motion a portion of the army to take military possession of the State, and threatened to subvert her government, and to subject her people to military rule; that the State was wholly inadequate to resist the power and force of the Executive Department of the United States. She therefore insisted that such protection could, and ought, to be afforded by a decree, or order, of this court in the premises. ${ }^{146}$

Although he would later, in $M c$ Cardle, reason that these Acts were unconstitutional for many of the same reasons Georgia put forth in Stanton, Stanbery argued not that the Acts were unconstitutional, but rather that the Court lacked jurisdiction to hear the case. ${ }^{147}$ Specifically, Stanbery argued that the question of whether Georgia even qualified as a state was a political question inappropriate for the Court to resolve. ${ }^{148}$ This time, the Court accepted Stanbery's argument. ${ }^{149}$

143. Id. at 112

144. 73 U.S. (6 Wall.) 50 (1867).

145. Id.

146. Id. at 52 .

147. Id. at 53-54 ("Our first objection is that we have not such parties here as authorize this court to entertain any case. Who is this controversy with? It is with officers of the United States of a very high grade. Is it with them as individuals? Not at all; but with them as officers of the United States, who have no State citizenship . . . Now, when you are asked to entertain the limited jurisdiction given to this court in an original case, and find that as to parties it must, by the terms of the Constitution, be a controversy between 'a State and citizens of another State,' is there anything that fulfils [sic] the idea of such a controversy?").

148. Id. at 56-57 ("Opposite counsel allege that Georgia is now a State of the Union, and ask the court to find that it is so. If they allege it as a matter of fact, we have a right to deny it; and what is the consequence? If this court has jurisdiction to decide that Georgia is a State, it has just the same jurisdiction to decide that Georgia is not a State, and that great political question, State or not a State, is settled and settled forever by this court.").

149. Writing for the Court, Justice Nelson explained, "the rights for the protection of which our authority is invoked, are the rights of sovereignty, of political jurisdiction, of government, of corporate existence as a State, with all its constitutional powers and privileges." Id. at 77. Justice Nelson held that the Court lacked jurisdiction to protect these rights and that the case had to be dismissed since " $[\mathrm{n}]$ o case of private rights or private 
In McCardle, however, it was Senator Trumbull who opened before the Court by denying jurisdiction for the case to be brought at all. ${ }^{150}$ Others since have asked why Stanbery himself could not have argued lack of jurisdiction, or some other point, and engaged cocounsel to handle the merits of McCardle's claim as had been previously done in Milligan. ${ }^{151}$ Stanbery had publically explained his position on the Reconstruction Acts in a speech at a Democratic Party banquet several days before the case was heard:

$[T]$ he Constitution is not silent. It has anticipated what has happened. It provides for insurrection, whether small or greatwhether of a part of a State or of an entire State, whether in one State or in many. .... Where, in this instrument, providing for the very case of insurrection, for the very remedy to be applied, where do you find the power to put down insurrection in a State, and then to destroy the State and hold it and its people as conquered and subjugated? ... Where does Congress find its warrant in time of peace to suspend the habeas corpus, to take away the inestimable privilege of trial by jury, ... and, finally, to try, to condemn, to punish, to imprison, to hang, these people for civil offences or pretended offences by the judgment of a military Court? . . . Gentlemen, I have been at the bar for nearly half a century, and have been a constant student not only of the common law, but of our own constitutional law; and I do not hesitate to say that the whole of these Reconstruction acts of Congress, from beginning to end, ... are unconstitutional and void. There are times when to be silent is to be unfaithful. There are times when men must speak out. ${ }^{152}$

It would later be alleged that Stanbery's speech-given in his capacity as a politician-was behind his refusal to appear before the Court. ${ }^{153}$ At the time, much of the congressional concern focused on

property infringed, or in danger of actual or threatened infringement, is presented by the bill, in a judicial form, for the judgment of the court." Id.

150. Trumbull's initial argument was that the Habeas Corpus Act of 1867 did not grant jurisdiction for this type of case to be appealed to the Supreme Court. Horace White, The Life of Lyman Trumbull 328 (1913) ("It was Trumbull's contention that McCardle fell within this exception [i.e., the "charged with military offenses" exception to the Act], and hence that the right of appeal so far as he was concerned, did not exist."); see also, D.F. Murphy, Argument of Hon. Lyman Trumbull in the Supreme Court of the United States, March 4, 1868, in the Matter of Ex Parte William H. McCardle, Appellant 3 (D.F. Murphy, ed., Wash., Government Prtg. Office 1868) ("I shall commence what I have to say by denying the jurisdiction of the Circuit Court under the act of February 5, 1867, to hear this cause; and if I establish that proposition, of course this court cannot entertain jurisdiction of it.").

151. Cong. Globe, 40th Cong., 2d Sess. 983 (1868).

152. Battle of New Orleans: Democratic Banquet at Washington in Honor of the Day, N.Y. Times, Jan. 9, 1868, at 1.

153. See Cong. Globe, 40th Cong., 2d sess. 983 (1868) (Statement of John Conness) (alleging that it was at this speech "where, for the first time, [Stanbery] developed, not 
the fact that, by announcing his decision at the convention, Stanbery was engaging in political showmanship-a charge leveled at every President or Attorney General since who has unilaterally declared an act unconstitutional. ${ }^{154}$ However, from this vantage point, it is not clear that scrutiny on the venue was logically founded. The basis that Stanbery's decision was motivated by his professional opinion, as provided to the President, appears to have been viewed as more ethically acceptable. ${ }^{155}$ Yet it is difficult to imagine a statute's proponents feeling particularly comfortable with an attorney who, in his non-legal, political capacity, declares a statute "unconstitutional and void," 156 but nevertheless officially purports to defend it. At its core, the objection appears not to have been that Stanbery should only have commented on the statute in his political capacity, but rather that he commented on it in a political capacity at all. ${ }^{157}$ Reaction in the press to Stanbery's decision was mixed. For example, the Daily National Intelligencer, a noted pro-Administration paper, ${ }^{158}$ lauded Stanbery's moral scruples when it wrote:

It occasioned no surprise among well-informed persons that the conscientious Attorney General should signify in open court, as he did yesterday, his disinclination to assume the post of advocate of the usurpers of Congress in the McCardle case in the Supreme Court .... [I] t is not for a lawyer of such eminent consistency in his constitutional views, and of such character as Henry Stanbery, to appear ... in a position directly opposite to his opinion, while able and zealous counsel are available who could defend General Ord without sacrifice of conviction. ${ }^{159}$

Newspapers supporting the Radical Republican elements ${ }^{160}$ of Congress, however, were less charitable. The Lowell Daily Citizen and News of Massachusetts bluntly declaring that "Mr. Stanberry [sic], the

before a court, but before a set of politicians organizing for the political control of the country, his conscientious scruples to further appear as an attorney in behalf of the United States where questions involving the acts of reconstruction were involved ...").

154. See supra notes 7-11 and accompanying text.

155. See generally infra note 184 .

156. See supra note 153.

157. See infra note 174 .

158. See Robert W. Winston, Andrew Johnson: Plebian and Patriot 532 (1969) (describing the Intelligencer as "President Johnson's organ").

159. Editorial, The McCardle Case, Nat'l Intelligencer, Jan. 11, 1868, at C.

160. Often contrasted with the "conservative" Republican faction, which included President Lincoln, the Radical Republicans were vehement abolitionists dedicated to racial equality and to the suppression of the unrepentant South. They were strong opponents of the conciliatory Reconstruction policies offered by Lincoln and Johnson. See generally Allan G. Bogue, Historians and Radical Republicans: A Meaning For Today, 70 J. Aм. Hist. 7 (1983) (analyzing the historical treatment of the Radical Republicans who were in Congress during the Civil War). 
federal attorney-general at Washington seems to have some very queer ideas as to his duties as the law-officer of the government."161 The paper went on to ask:

We would like to know whether Mr. Stanberry [sic] is the Attorney General of the United States, and as such bound to uphold and defend the laws of his government, or is the private attorney of Mr. Andrew Johnson, who is doing all he can to break down the laws, and thwart the intentions of the law making power of the government?

According to his own statement he is now filling the latter position, and we recommend him to surrender his portfolio to someone who will attend to the duties of the office, and appear on behalf of the United States, when their interests are dragged into court. ${ }^{162}$

These newspaper columns represent the two basic reactions to Stanbery's announcement, both among the press and among the legal and political world generally: respect for Stanbery's refusal to adopt a legal position in which he did not believe, versus contempt that the government's lawyer refused to represent the government.

Curiously, there was little congressional response to Stanbery's decision at the time. For Congress, the crisis presented by the Supreme Court's decision to advance McCardle, regardless of Stanbery's participation, posed a very real possibility that the Reconstruction Acts would be struck down. Contemporary belief was that the Court's decision to advance the case on the docket had been decided by a vote of $5-4$, and thus a hearing on the merits would result in the same outcome. ${ }^{163}$ Faced with the likelihood of such a devastating defeat, Congress had little time to criticize the actions of the Attorney General. ${ }^{164}$ For his part, Trumbull made a series of motions and arguments designed to slow down the appeal. ${ }^{165}$ Meanwhile, the members of Congress made preparations to repeal the Court's jurisdiction over the case. ${ }^{166}$

161. Lowell (Mass.) Daily Citizen and News, Jan. 15, 1868, at E.

162. Id.

163. Charles Warren, 3 The Supreme Court in United States History 187-88 (Beard Books 1999) (1922). The expectation was that Justices Grier, Clifford, Nelson, Davis, and Field would vote to strike down the Acts. Id. Indeed, Chief Justice Chase later wrote to Judge Hill that "had the merits of the McCardle Case been decided the Court would doubtless have held that [McCardle's] imprisonment before a military commission was illegal." FAIRman, supra note 17, at 494.

164. Also distracting Congress, as McCardle percolated, was Congress's simultaneous attempt to impeach Andrew Johnson. The timeline of these various events is highly overlapping. For a detailed discussion of these competing chronologies, see FAIRMAN, supra note $17,450-67$.

165. See FAIRMAn, supra note 17 , at 451 .

166. See Burgess, supra note 124, at 197. 
Stanbery's decision not to appear was not debated in Congress until the end of February 1868, and even then, only somewhat tangentially. The impetus for that debate was yet another case challenging the validity of the Reconstruction Acts: Georgia v. Grant. ${ }^{167}$ Knowing Stanbery would not appear, Secretary of War Edwin Stanton, sent a letter to the Senate asking for "a joint resolution authorizing the Secretary of War to employ counsel for the purpose" of defending the generals who were named as defendants. ${ }^{168}$ It seems likely that the request from Stanton was, at least in part, intended to draw political attention to Stanbery's refusal. After all, as Thomas Hendricks of Indiana pointed out, it was not at all clear that it was "necessary to pass [the] resolution, in view of the fact that the Departments, including the War Department, [had] been in the habit of employing counsel at their discretion." 169 While the resolution's passage was widely considered a foregone conclusion, ${ }^{170}$ congressional debate over the resolution allowed the members of Congress to officially weigh in on the propriety of the Attorney General's actions. Comments given during the Senate debate on the resolution followed the same general structure of that already being had in the media. For example, Jacob Howard of Michigan, a well-known Radical, ${ }^{171}$ was outraged:

167. 73 U.S. (6 Wall.) 241 (1868). Grant was a follow-on case to Georgia v. Stanton, 73 U.S. (6 Wall.) 50 (1868). It was thought that Grant had presented an argument that solved some of the jurisdictional questions that had undermined Stanton. The basic facts involved the decision of General Meade to remove the Governor and the State Treasurer for refusing to levy certain taxes and to appoint two military officers to those positions. The recently deposed Governor took the money from the state's treasury and fled to New York, while filing suit against the various military officers involved in the case. Because the money had been removed, the military was required to seize certain state property to fund their operations. Accordingly, Georgia was not only able to allege that it was a free state that was entitled to constitutional protections, but also that it was the owner of a considerable amount of property that had been seized by the defendants and establish the property claim that the Court had been looking for in the Stanton case. See FaIrman, supra note 17, at 434-36.

168. Letter from Secretary of War Edwin Stanton to Senator Henry Wilson (Feb. 5, 1868), reprinted in Cong. Globe, 40th Cong., 2d Sess. 981 (1868).

169. Cong. Globe, 40th Cong., 2d Sess. 981 (1868). Hendricks suggested Stanton's request was "simply a parade of the matter for some purpose beyond the mere necessity of obtaining congressional permission to do the thing asked." Id. at 983.

170. The only real objections were from Senator Hendricks, who viewed it as unnecessary and saw it as a political stunt, $i d$., and Reverdy Johnson, who wanted to make sure that the resolution was confined to cases arising under the Reconstruction Acts. Id. at 981 . The Resolution passed the House by a vote of 115 to 37. Id. at 992.

171. See generally Earl Maltz, Radical Politics and Constitutional Theory: Senator Jacob M. Howard of Michigan and the Problem of Reconstruction, 32 Mich. Hist. Rev. 19, 20 (2006) (noting that Howard had been described as a "consistent radical" and "part of the "radical nucleus' within the Republican party"). 
It is notorious that the Attorney General of the United States, whose duty it would be ordinarily to appear as counsel . . . and whose duty it is by the law of the land so to appear, has, upon a very important occasion, declined to appear for [the War] Department in the Supreme Court . . . .

... It seems to me strange, sir, that an office of that high grade and of that solemn responsibility should, under any circumstances, before a judgment has been pronounced by the Supreme Court of the United States, have entertained and expressed the opinion that the legislation of Congress was unconstitutional and void. ${ }^{172}$

Similarly, John Conness of California observed that,

[I]t would have become the Attorney General, the day and the hour that he could not appear in behalf of laws passed by the Congress of the United States and for their vindication in the courts of the country, to lay down his commission and retire to private practice. $^{173}$

On the other hand, supporters claimed that Stanbery had done nothing more than perform his duty as an attorney. For instance, Garrett Davis of Kentucky declared that Stanbery had merely given the President his legal opinion that the Reconstruction Acts were unconstitutional and therefore had "shown no dereliction in the performance of his duty in [the] matter."174 Thomas Hendricks, a Democrat from Indiana and prominent opponent of the Reconstruction Acts, ${ }^{175}$ spoke at length about the duties of an attorney:

[Is it] the duty of the Attorney General to go before [the Supreme Court] and make an argument that he does not believe? I wish I had before me the statutes of the State of Indiana, which . . . [declare] that [an] attorney shall be true to the court in an argument of a question of law and true to the jury in the argument of a question of fact. ... . [T] he Attorney General or any other attorney, whether employed by the Government or otherwise, must speak what he believes to be the law. ${ }^{176}$

John Sherman of Ohio, a moderate Republican who was a noted opponent of President Johnson, ${ }^{177}$ as well as the younger brother to noted Union General William T. Sherman, offered a similar defense of the Attorney General:

I do not think the Attorney General ought to be called upon in any case to act where he has openly committed himself to the opinion

172. Cong. Globe, 40th Cong., 2d Sess. 981-82 (1868).

173. Id. at 983 .

174. Id. at 982 .

175. See John W. Holcombe \& Hubert M. Skinner, Life and Public Services of Thomas A. Hendricks 265-69 (1886).

176. Cong. Globe, 40th Cong., 2d Sess. 983 (1868).

177. Theodore E. Burton, 2 american statesmen, Second Series, John Sherman 158 (Standard Library ed. 1906). 
that the law which he is defending is unconstitutional. I am not disposed to cast stones at the Attorney General for this opinion, because he was required, in performing the highest duty of his office, in giving advice to the President of the United States, to pass semi judicially upon these laws .... . He undoubtedly gave the opinion ... that the principal, main, and leading provisions of the reconstruction acts are unconstitutional. I have no doubt that the Attorney General was honest in that opinion .... He having given that opinion and come to that conclusion, as a matter of course it is improper for Congress to call upon him to contend for the constitutionality of the very acts which he has pronounced unconstitutional. ${ }^{178}$

Echoing arguments regarding the inherent duties of an attorney, Reverdy Johnson of Maryland also supported Stanbery's decision. Noting that Stanbery had already publically offered an opinion on the Reconstruction Acts, an opinion no one contended was insincere, Johnson asked,

Suppose that [Stanbery] was to appear in the Supreme Court . . . and [have] his own opinion . . . cited against him, what answer could he make? Could he say that he had changed that opinion? ... It would therefore, in my view, have been very improper in [sic] him to appear in the Supreme Court in these cases, because it would not be doing justice to the controversy, to the legislation of Congress. It is much better that the laws . . be vindicated by counsel who have not only not given any opinion to the contrary, but who entertain an opinion in consonance with the views of Congress . . . . ${ }^{179}$

As it was a widely deemed a foregone conclusion that the funds would be approved, the House debate on the resolution was much shorter and largely mocking. When James Garfield of Ohio introduced the resolution, Glenni Scofield of Pennsylvania sarcastically remarked that he had been under the impression that "we had an Attorney General, whom we paid a high salary, to perform this duty; and I want to ask the gentleman what has become of him, and why he is not on hand to plead the cause of our country before the courts?" 180 Garfield responded, hypothesizing that perhaps the Attorney General was so busy "writing vetoes of reconstruction bills and making speeches to Democratic meetings ... that he cannot give his attention to a matter of this sort." 181 When Samuel Randall of Pennsylvania expressed concern over the amount of money that might be expended on outside counsel, as well as the danger that the executive might

178. Cong. Globe, 40th Cong., 2d Sess. 982 (1868).

179. Id.

180. Id. at 991

181. Id. 
potentially employ political cronies as outside counsel when they were not truly necessary, Garfield quipped, " $[\mathrm{t}]$ he only reason this joint resolution is necessary is because the Attorney General has gone over to [Randall's] party and is declaring in open court that he declines to act for the Government in cases of this sort." 182 When an overwhelming majority nonetheless passed the resolution, Abner Harding of Illinois jokingly suggested its title be amended to "a joint resolution to supply executive deficiencies without impeachment."183

It is worth noting that, while legitimate objections were raised over the lack of congressional oversight in a bill which authorized the executive to hire outside counsel without further authorization, and while Congressman Randall's concerns regarding the danger that employing outside counsel would turn into a patronage system were legitimate, no one seemed to seriously believe that Stanbery should have appeared before the Supreme Court in either McCardle or Grant. Partisan joking aside, the core of congressional objection concerned Stanbery's declaration that the law was unconstitutional in the first place. While there was some dispute over whether Stanbery had made that declaration in a private or formal capacity, ${ }^{184}$ there was little disagreement that once he had done so, he ought to be disqualified as counsel. ${ }^{185}$ Claims that the resolution should never have been necessary rested not on the view that Stanbery should be compelled to appear on the United States' behalf, but on the notion that it was inappropriate for him to be passing judgment on the constitutionality of statutes. ${ }^{186}$ Alternatively, opponents believed that, once he could not in good faith defend an act of Congress, Stanbery should have

182. Id. at 992.

183. Id.

184. Compare Cong. Globe, 40th Cong., 2d Sess. 983 (1868) ("Mr. Conness: 'The first time ... that I have any recollection [of Stanbery's indicating that the Acts were unconstitutional] was at a certain political celebration . . . where, for the first time, he developed, not before a court, but before a set of politicians . . . his conscientious scruples." ), with id. at 982 ("Mr. Davis: 'In the first place, he said he had been called upon officially by the President of the United States to give his opinion in relation to the validity of the constitutionality of the reconstruction acts . . . [and, having advised that they were unconstitutional] he therefore declined to appear.'”).

185. Instead, the debate was over whether Stanbery should have offered the opinion at all and once offered whether the appropriate course was to resign his office. See supra notes 172-82. Stanbery was heavily involved in the decision to veto the acts, so it seems likely that he sincerely believed them unconstitutional from the outset. See Paul H. Bergeron, AnDRew Johnson's Civil War and Reconstruction 151-53 (2011).

186. See Cong. Globe, 40th Cong., 2d Sess. 982 (1868). 
resigned as Attorney General. ${ }^{187}$ In essence, Congress's objections to Stanbery's decision mirror what would eventually become the stated, if not always followed, position of future Attorneys General: That it is not "the prerogative of the Executive ... to exercise free and independent judgment on constitutional questions presented by Acts of Congress." 188

The final voice that might be expected to have weighed in on the issue is that of the Supreme Court itself. Unfortunately, there is little documentation available that directly addresses the Court's opinion of Stanbery's refusal to appear. One clue can be seen in a letter written to Gerrit Smith, a leading New York abolitionist, ${ }^{189}$ by Chief Justice Chase:

Nothing is clearer to my mind than that acts of Congress not warranted by the Constitution are not laws. In case a law believed by the President to be unwarranted is passed, notwithstanding his veto, by the required two-thirds majority, it seems to me that it is his duty to execute it precisely as if he held it to be constitutional, except in the case where it directly attacks and impairs the Executive power confided to him by the Constitution. In that case it seems to me to be the clear duty of the President to disregard the law, so far at least as it may be necessary in order to bring the question of its constitutionality before the judicial tribunals. ${ }^{190}$

Chase appears to be taking a fairly limited view towards the propriety of declining to defend acts of Congress, although tacitly endorsing that practice in situations where Congress' action presents a separation of powers problem itself. Chase presents a view of the executive's duty to defend which closely mirrors the modern conception. ${ }^{191}$ In his letter, Chase draws the same exception to the general rule that has become the core of modern practice, which holds that the executive's duty to defend statutes is abrogated only where they infringe upon the separation of powers. In those cases, the duty can be defied, but only insofar as is necessary to make the issue judiciable.

187. Id. at 983 ("Mr. Conness: 'I think it would have become the Attorney General, the day and the hour that he could not appear in behalf of the laws passed by the Congress ... to lay down his commission and retire to private practice.'”).

188. 4A Op. O.L.C. 55, 59 (1980).

189. See Kevin P. S. Tanner, “A Foe to Sad Oppression's Rod:" The Story of Gerrit Sмiтн 3 (2008) (describing Smith as "America's leading political abolitionist").

190. Letter from Chief Supreme Court Justice Salmon P. Chase to Gerrit Smith (Apr. 19, 1868), reprinted in J.W. Schukers, The Life and Public Services of Salmon Portland Chase 577 (1874).

191. See supra Part I.B. 


\section{Subsequent Developments: The Outcome of McCardle and the Creation of the Department of Justice}

Congress managed to pass legislation removing jurisdiction from the Court on March 12, 1868; 192 three days after the oral arguments but before the justices had met in conference. When the Court finally met on March 21, they postponed consideration of McCardle since, while the bill stripping jurisdiction over the pending action had been passed by both the House and the Senate, it had not yet been addressed by the President. ${ }^{193}$ On March 25, President Johnson vetoed the bill, warning that it "establishe[d] a precedent which, if followed, may eventually sweep away every check on arbitrary and unconstitutional legislation." ${ }^{194}$ Both chambers overrode his veto, the Senate on March $26^{195}$ and the House on March 27. ${ }^{196}$ Amid much contemporary controversy, and over the impassioned dissent of two Supreme Court justices, the Court set over the case until the following term. ${ }^{197}$ The next year, the Court heard additional argument on whether the repeal act had affected the McCardle case. ${ }^{198}$ On April 12, 1869, the Chief Justice announced the opinion of the Court: "It is quite clear . . . that this court cannot proceed to pronounce judgment in this case, for it has no longer jurisdiction of the appeal." The appeal was dismissed for want of jurisdiction ${ }^{199}$ and the merits of the Reconstruction Acts were never reached. The case has become highly influential for its ultimate resolution, and a staple of Federal Courts classes nationwide; the legacy of McCardle is how it accentuated the tension existing between congressional and judicial power. ${ }^{200}$

192. See Act of Mar. 27, 1868, ch. 34, 15 Stat. 44 (1868) (repealing the Habeas Corpus Act of 1867 "as authorizes an appeal from the judgment of the circuit court to the Supreme Court of the United States, or the exercise of any such jurisdiction by said Supreme

Court on appeals which have been ... taken"); supra note 121.

193. FAIRMAN, supra note 17 , at 467-68.

194. Cong. Globe, 40th Cong., 2d Sess. 2094 (1868).

195. Id. at 2128 .

196. Id. at 2170 .

197. See FaIRman, supra note 17 , at $475-76$.

198. Ex parte McCardle, 74 U.S. (7 Wall.) 506, 510 (1869).

199. Id. at 513.

200. See, e.g., Stanley Kutler, Judicial Power and Reconstruction Politics 89-113 (1968) (relating and then challenging accusations of "cowardice" and "impotence" directed at the Reconstruction era Court, with reference to the McCardle case); Van Alstyne, supra note 112, at 244-54 (discussing whether the Court should have simply ignored the repeal act and ruled on the merits of $M c$ Cardle). McCardle has also been of recent interest in cases involving detainees in the War on Terror. See Hamdan v. Rumsfeld, 548 U.S. 557, 657 (2006) (Scalia, J., dissenting) (citing McCardle for the proposition that "statutes ousting jurisdiction terminate jurisdiction in pending cases"). 
In 1870, Congress undertook to create a Department of Justice. ${ }^{201}$ This was the culmination of several attempts to create a legal department within the federal government. The move was, at least in part, motivated by a desire to consolidate the government's lawyers in hope of achieving a more unified interpretation of the law. ${ }^{202}$ Another primary goal was to reduce the amount of money spent on outside counsel. ${ }^{203}$ While some members of Congress expressed a straightforward interest in reducing government expenditure overall, ${ }^{204}$ the Senate seemed less troubled by the money spent than by the fear that it was used to hire political favorites of the official engaging the outside counsel. ${ }^{205}$ No mention was made in either the House or the Senate debates on that bill of the Attorney General's refusal to appear in McCardle. One reason for that might be that the Bill itself predated Stanbery's announcement, although the congressional debate took place afterwards. ${ }^{206}$ Nevertheless, the unifying goal of the Bill was clear: Congress sought to avoid situations in which the executive hired outside lawyers to represent the United States in federal court. ${ }^{207}$

201. Act of June 22, 1870, ch. 150, 16 Stat. 162 (1870) (establishing the Department of Justice).

202. See generally Cummings \& McFarland, supra note 12, at 218-25.

203. The entire Senate debate on the bill was to clarify that the purpose of the department was to "cut off [the] extra and unnecessary expense to the [g] overnment" of employing outside counsel. Cong. Globe, 41st Cong., 2d Sess. 4490 (1870).

204. See id. at 3065 (" $[\mathrm{T}]$ he bill is important in order to save the unnecessary expenditure of more than one hundred thousand dollars annually for extra-official fees to counsel.").

205. Id. at 4490 ("The object of the bill is the prevention of what I may call the sporadic system of paying fees to persons . . . who may be called department favorites."). The widespread practice of engaging outside counsel serves to further bolster Senator Hendricks' view that the introduction of the resolution authorizing counsel in the Grant case was nothing more than a political exercise to draw attention to Stanbery's refusal to appear. See supra note 169 .

206. On December 12, 1867, a resolution instructed the Judiciary Committee to explore the consolidation of the various attorneys in the executive branch into "the Attorney General's department." Cong. Globe, 40th Cong., 2d Sess. 153 (1867). Indeed, the creation of a Law Department had been in progress since an 1854 report from Attorney General Cushing to President Pierce. See A Report of the Attorney General Suggesting Modifications in the Manner of Conducting the Legal Business of the Government, H.R. Exec. Doc. No. 95 (1854).

207. See supra note 205. The bill's main proponent in the House, Representative Thomas Jenckes of Rhode Island, was concerned with ensuring that "no person should be charged with the conduct of litigation in behalf of the United States unless he holds a commission under the United States and is responsible to the law and the proper authorities." Cong. Globe, 41st Cong., 2d Sess. 3035 (1870). 
In order to specifically deal with the problem of the Attorney General's ability to represent the Government effectively, the Bill proposed to "create ... a new officer, to be called the solicitor general of the United States, part of whose duty it shall be to try these cases in whatever courts they may arise."208 The scope of the Solicitor General's duties was quite broad. He was to be an individual "of sufficient learning, ability, and experience that he can be sent to New Orleans or to New York, or into any court wherever the Government has any interest in litigation, and there present the case of the United States as it should be presented." 209 It is not entirely clear how one additional lawyer was intended to solve a problem that required the employment of so many outside attorneys, since the primary effect of creating a law department was to consolidate existing positions. If, indeed, outside counsel was hired because the caseload was too heavy for the government attorneys to handle, a simple reorganization would not have solved that. However, it is clear that this new officer was meant to represent the United States and assume the Attorney General's duty to appear in the courts. It is possible Congress hoped that, by dividing the Attorney General's obligation to give legal opinions from the Solicitor General's obligation to represent the government, the problem faced by Stanbery in McCardle could be avoided in the future. After all, an officer whose sole job is to appear in litigation would have no occasion to render official opinions on laws. ${ }^{210}$

\section{Questions Raised and Lessons Learned}

Stanbery's decision not to appear in McCardle caused uproar. Nonetheless, Stanbery's actions serve as a guide for how to properly make such a refusal. In both Marbury and Hudson $\mathcal{E}^{2}$ Goodwin, the Attorney General's refusal to appear effectively ended the case-or at least barred advocacy of a particular position. This result threatened the legal system by allowing an Attorney General's refusal to potentially usurp the roles of both the judiciary and the legislature. As a preeminent and experienced attorney, Stanbery would certainly have been familiar with the precedents set by Marbury and Hudson $\mathcal{E}$ Goodwin and, either by accident or design, took actions to ameliorate the serious concerns those cases raised. Specifically, he announced his de-

\footnotetext{
208. Id. at 3035 .

209. Id.

210. Ironically, the relationship of the Solicitor General to the President, to Congress, and to the courts would eventually become a source of great debate as the office developed and the federal government continued to expand. See supra note 12.
} 
cision publicly as well as before the Court, which provided notice to interested parties in time to arrange an intervention, and took steps to ensure that the law would be defended by able counsel before he personally withdrew. ${ }^{211}$ By these actions, Stanbery demonstrated the best possible mechanism for an Attorney General to permissibly decline to defend certain statutes.

While McCardle presents the issue of an Attorney General's ability to refuse to defend an act of Congress in its purest form, it also artificially exaggerates the problem. At the time of Stanbery's decision, the Attorney General's office consisted of only Stanbery himself, two nonlawyer assistants, and a clerical staff. ${ }^{212}$ Thus, the decision of the Attorney General necessarily became the decision of the entire department. This characteristic makes it easy to conflate the professional decision made by Henry Stanbery as an attorney with that made by the Office of the Attorney General. In the present era, with the Department of Justice heralding itself as the "world's largest law office," 213 decisions made by the department not to appear are more pronounced as those decisions can no longer arise simply out of the conflict existing between the official position and the legal opinion of a single attorney. Most discussion of Stanbery's decision has focused on whether he, as Attorney General, should have been compelled to make an argument in defense of a statute that he and the President believed to be unconstitutional. The starting point for analyzing that issue is to answer the question: who was Stanbery's client? While the Attorney General has a statutory responsibility to appear on behalf of the United States, the scope of that obligation depends on whether one views that duty as being owed primarily to the President, to the Congress, or as one former Attorney General believed, simply to the country. ${ }^{214}$ If the Attorney General is viewed first as the attorney for the executive branch, then he would be well within his professional rights to decline to make an argument or to pursue a case at the behest of the President. If, however, the Attorney General's primary client is Congress, the drafters of the statute at issue, or the United States in general, then the scope of his duty to defend becomes less clear. In that case, his duty to his client can become outright contradictory as he seeks to balance competing interests.

211. See supra Parts II.A, II.B.3.

212. Cummings \& MacFarland, supra note 12, at 223.

213. See About the Office, U.S. Dep't of Justice, Office of Att'y Recruitment Mgmt, (Aug. 2011), http://www.justice.gov/oarm/about-office.html ("The Department of Justice is the world's largest law office, employing more than 10,000 attorneys nationwide.").

214. Francis Biddle, In Brief Authority 98 (1962). 
Stanbury faced an ethical dilemma. First, all clients have "a right to have [their] case decided upon the law and . . . to have every view presented to the minds of the judges which can legitimately bear upon the question." ${ }^{215}$ For Stanbery, however, this duty contrasted against the equally well-accepted principle that an attorney must not misstate the law to the court. ${ }^{216}$ Stanbery believed the Acts were unconstitutional, and to declare otherwise before the Court might seem dishonest. On the other hand, it is a clear dereliction of duty for an attorney to abdicate a client's position simply because he thinks that he will not, or even should not, prevail. From this perspective, Stanbery's dilemma raises the question, perhaps irresolvable, of what action a lawyer should take when faced with the duty to defend a law that he believes, in his professional opinion, is unconstitutional. On the one hand, "the lawyer who refuses his professional assistance because in his judgment the case is unjust and indefensible usurps the [function] of [the] judge." 217 On the other hand, the Attorney General is not a normal attorney presented with a case in which he doubts the merits of his client's position. As counsel to the United States, his position carries with it an additional level of credibility and perhaps a heightened privilege of independent review, such that his decision to decline to adopt a certain position should perhaps be scrutinized differently than that of a private attorney.

Stanbery's position in McCardle was particularly ethically precarious. He not only believed that the Reconstruction Acts were unconstitutional, but had also given public opinions to that effect. Stanbery's situation is analogous to that of an attorney who, in his professional writings, takes a strong position on a timely legal issue. If subsequently asked by a client to argue the other side in some pending legal matter, could that hypothetical lawyer properly do so?218 Could he realistically fulfill his duty to provide competent representation to the client while arguing a legal position he has already convinced himself is incorrect? These questions cannot be answered in the space allotted, yet surely

215. George Sharswood, Professional Ethics 83 (5th ed.1907).

216. See George W. Warvelle, Essays in Legal Ethics 195-96 (Callaghan \& Co. 1920) ("It is one of the ancient duties of counsel to advise the court with respect to the law of the particular case in which he appears. ... In discharge of this duty counsel is required exercise the utmost candor ....”). This principle remains in effect today. See Model Rules of Prof'l Conduct R. 3.3 (“A lawyer shall not knowingly make a false statement of fact or law to a tribunal ....").

217. SHARswoOd, supra note 215 , at 83 .

218. The danger, as raised by Reverdy Johnson, is that the attorney's credibility and effectiveness before the court would be so threatened by the apparent inconsistency that he must be forced to withdraw as counsel. See supra note 170 and accompanying text. 
bear on any assessment of Stanbery's decision to withdraw from the $M c$ Cardle case. A separate question asks whether, even if Stanbery was ethically correct in refusing to appear, the more appropriate course of action would have been for him to resign his office? After all, that would seem the usual and expected course of conduct for a private attorney unable to provide effective representation to a client for whatever reason.

The more significant concerns raised by an Attorney General's refusal to defend an act of Congress relate to the integrity of the adversarial process and to the preservation of the system of checks and balances. The adversarial system is the "hallmark of American adjudication." 219 It is thought to enhance the quality of the resulting determinations by assuring that competing positions are fully and vigorously advanced. That no one appeared on behalf of Madison in Marbury created a situation in which Marbury's attorney conducted the entire trial opposed by nothing but the questioning of the Justices themselves. Potential repercussions caused by this lack of a true adversary in Marbury were ameliorated, perhaps, by the fact that the executive clearly opposed Marbury's application for a writ. As that case involved a challenge to executive power, the refusal to appear worked, essentially, as the executive's consent to a trial in absentia. In contrast to fully adversary proceedings, however, such consent does nothing to assure that the issues are fully explored or that relevant arguments are presented and tested.

The situation was worse in Hudson $\mathcal{E}$ Goodwin. Of all the cases discussed here, the actions of the Attorney General in Hudson $\mathcal{E}$ Goodwin posed the greatest risk to the legal system. Even though Attorney General Pinkney, too, simply refused to argue a position that he believed was incorrect, that decision effectively prevented any resolution of the issues presented. By not appearing, Pinkney eliminated the controversy from the case: the defendant believed the case should be dismissed and the government refused to argue otherwise. Similarly, in Coolidge, the Attorney General prevented the issue from being heard at all, simply by refusing to appear. There seems a clear danger in allowing an Attorney General's decision not to appear to preclude judicial review.

219. Ellen E. Sward, Values, Ideology, and the Evolution of the Adversary System, 64 IND. L.J. 301, 301 (1989); see also Muskrat v. United States, 219 U.S. 346, 361 (1911) ("[The] judicial power . . . is the right to determine actual controversies arising between adverse litigants, duly instituted in courts of proper jurisdiction.”) (emphasis added)). 
Any system that allows the Attorney General to refuse to argue in defense of an act of Congress necessitates an alternative mechanism by which some party would have standing to defend the statute. Traditionally, Congress lacked its own legal staff able to intervene in cases and relied on the Attorney General to represent its legal interests. ${ }^{220}$ In cases where the Attorney General refused to appear, such as McCardle, or where the Attorney General argued against the controlling statute, such as Myers, members of Congress were forced to appear in their personal capacities to argue the cases. In McCardle, for example, the War Department made arrangements to hire two sitting senators. ${ }^{221}$ In Myers, Senator Pepper appeared at the request of the Court as amicus curiae. ${ }^{222}$

This state of affairs changed in 1978 with the establishment of the Senate Legal Counsel, which was given responsibility to intervene "in any legal action or proceeding ... in which the powers and responsibilities of Congress under the Constitution of the United States are placed in issue."223 This change addressed the Myers and Chadha manner of cases that directly implicate powers of Congress in relation to the powers of the President. However, the Senate Legal Counsel was also given the duty to "defend vigorously when placed in issue- . . . the constitutionality of Acts of Congress." ${ }^{224}$ Together, these arrangements allow for Congress to better defend its interests and, in a sense, place the Attorney General more fully within the executive branch. Any overlapping duties, such as the provision of legal opinions, are now dealt with by the appropriate congressional office. However, we may someday find ourselves discussing some of these same issues in the context of a refusal by a Senate Legal Counsel to defend a statute that he considers to be unconstitutional.

\section{Conclusion}

Despite protestations to the contrary, Attorneys General have refused to argue the position of "the United States" before the Supreme Court dating back to the country's founding. Those refusals have implicated concerns regarding the separation of powers, the nature of

220. See Rebecca Salokar, The Solicitor General: The Politics of Law 87 (1992).

221. See supra Part II.B.3.

222. Myers v. United States, 272 U.S. 52, 176 (1926).

223. 2 U.S.C. $\$ 288 \mathrm{e}(\mathrm{a})$ (2006).

224. Id. $\S 288 \mathrm{~h}(7)$. The Speaker of the House's legal counsel has been given similar duties, albeit through the House's internal rules. Days, supra note 12, at 502. 
the legal process, and even the personal duties of an attorney to his client.

There are two widely recognized situations in which the Attorney General need not, and perhaps should not, defend an act of Congress against a constitutional challenge.

The first applies where a statute infringes upon the powers constitutionally granted to the executive. This exception recognizes the fundamental reality that "the government" is not a monolithic entity with a single voice, but rather a collection of co-equal branches, and subordinate departments, who will, at times, find themselves in conflict. Permitting the Attorney General to refuse to defend, or to actively oppose, a statute in this context, merely acknowledges this fact. It acknowledges that "the United States" might not, actually, constitute a single party to a proceeding and it recognizes the Attorney General's traditional role as a member of the executive branch.

The second exception, forgiving the duty where no credible argument can be made in defense of a statute, is similarly straightforward. It shows respect for the power of precedential decisions while acknowledging the finite resources of the court system by recognizing that if a statute is very similar to one that has been struck down, it is often not a productive use of governmental resources to defend it. In practice, however, there can be strong differences of opinion as to whether credible arguments exist.

Of course, there is still a third category governing situations in which the President believes a statute to be unconstitutional before, or even in spite of, a court's ruling. This Article has sought to explore some of the earliest and most significant cases concerning that category. At its narrowest, this Article contends any claim that the refusal to defend is a recent development is historically false. More broadly, this Article has drawn out the historical debate surrounding Attorney General Stanbery's decision not to appear in Ex Parte McCardle-a debate which closely mirrors debates had over similar decisions todayand attempted to identify the potential issues presented by the practice. By examining these early cases, this Article attempted to present a wide range of potential situations in which the Attorney General might decline to appear.

Beyond any professional issues raised by the withdrawal of counsel, the most important considerations in analyzing an Attorney General's decision not to appear are the maintenance of the adversarial system and ensuring the effective separation of powers with checks and balances. Interested parties must be allowed to defend their inter- 
ests, even where the customary party chooses not to. Stanbery's efforts to make sure that the War Department engaged counsel in McCardle, as well as the subsequent creation of legal offices within the Congress to handle such suits, did much to alleviate the dangers posed by Stanbery's decision, and provides an important lesson for analyzing similar situations today. While the decision not to defend a statute inevitably invites controversy and criticism, an Attorney General does much to maintain the dignity of his office by taking steps to provide for the vigorous defense of acts of Congress. Whatever the merits of such a decision, those decisions are well-precedented and, provided that some process is available through which to provide the act with a legal defense, the decision not to defend an act does not pose a substantial risk to our system of government. 
